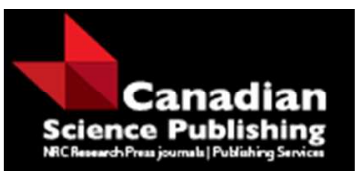

Canadian Journal of Forest Research Revue canadienne de recherche forestière

\title{
Effects of loblolly pine litter, forest floor and root exclusion on mineral soil carbon in a Florida Spodosol
}

\begin{tabular}{|r|l|}
\hline Journal: & Canadian Journal of Forest Research \\
\hline Manuscript ID & cjfr-2015-0097.R2 \\
\hline Manuscript Type: & Article \\
\hline Date Submitted by the Author: & 26-Sep-2015 \\
\hline Complete List of Authors: & $\begin{array}{l}\text { Stoppe, Aja; University of Florida, Soil and Water Science } \\
\text { Comerford, Nicholas; University of Florida, North Florida Research \& } \\
\text { Education Center } \\
\text { Jokela, Eric; University of Florida } \\
\text { Mackowiak, Cheryl; University of Florida, North Florida Research \& } \\
\text { Education Center } \\
\text { Higa, Rosana; Empresa Brasileira de Pesquisa Agropecuária, Forestry }\end{array}$ \\
\hline Keyword: & soil carbon, leaf litter, root, Pinus taeda L., soil size fraction \\
\hline & \multicolumn{2}{|c}{} \\
\hline
\end{tabular}

\section{SCHOLARONE ${ }^{m}$}

Manuscripts 
1 Article Title:

2

3 Effects of loblolly pine litter, forest floor and root exclusion on mineral soil

4 carbon in a Florida Spodosol

5

6 Authors:

7 A.M. Stoppe ${ }^{1}$, N.B. Comerford ${ }^{1,2^{*}}$, E.J. Jokela ${ }^{3}$, C.L. Mackowiak ${ }^{2}$, R.C.V. Higa ${ }^{3,4}$

8

$9 \quad{ }^{1}$ Soil and Water Science Department, University of Florida, PO Box 110510, Gainesville,

10 FL 32611, USA. ${ }^{2}$ North Florida Research and Education Center, University of Florida,

11155 Research Road, Quincy, FL 32351, USA. ${ }^{3}$ School of Forest Resources and

12 Conservation, University of Florida, P.O. Box 110410, Gainesville, FL 32611-0410,

13 USA. ${ }^{4}$ Empresa Brasileira de Pesquisa Agropecuária (EMBRAPA), Estrada de Ribeira

14 Km 111Colombo, Paraná, Br.

15 *email: nbc@ufl.edu, phone: (850) 875-7116 
17 Article Title:

Effects of loblolly pine litter, forest floor and root exclusion on mineral soil carbon in a Florida Spodosol

\section{Abstract}

Quantifying soil organic carbon (SOC) inputs in the surface soil is a critical component for assessing the potential for $\mathrm{C}$ sequestration of managed pine forests.

This study used a sequential exclusion of aboveground litter inputs ( $L=$ litter exclusion) and above plus belowground inputs ( $\mathrm{LR}=$ litter and root exclusion) to segregate $\mathrm{C}$ sources contributing to the development and maintenance of SOC in the surface soil

27 supporting juvenile loblolly pine (Pinus taeda L.) in its rapid growth phase. The study spanned the $7^{\text {th }}$ to $10^{\text {th }}$ year of stand growth. Soil physical size fractions $(>2 \mathrm{~mm}, \leq 2 \mathrm{~mm}$, 2000-250 $\mu \mathrm{m}, 250-150 \mu \mathrm{m}, 150-53 \mu \mathrm{m}$, and $<53 \mu \mathrm{m})$ were used to investigate the change in native SOC over time in the untreated control plots (UC=untreated control)

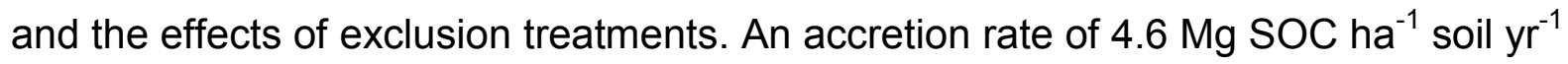
was observed in the fine earth fraction $(\leq 2 \mathrm{~mm})$, reflecting the rapid phase of stand growth. The accretion was primarily observed in the upper $10 \mathrm{~cm}$ of the soil. Treatment effects were most apparent in soil bulk density, SOC of the fine earth, and 150-53 $\mu \mathrm{m}$ intermediate increase between the UC and LR treatments; where only the removal of roots provided no change in SOC and was significantly different from the control $(p=$ 0.05). We conclude that a major contributor to the maintenance and increase of SOC in 
39 this fast-growing pine ecosystem was due to root turnover (60\%), with $40 \%$ due to 40 above-ground litter inputs.

41 
43 Abbreviations

44 BD bulk density

45 C carbon

$46 \mathrm{~cm} \quad$ centimeters

47 d day

48 ha hectare

$49 \mathrm{Kg} \quad$ kilogram

$50 \mathrm{~L} \quad$ aboveground litter exclusion treatment

51 LOI loss-on-ignition

52 LR above- and belowground litter exclusion treatment

$53 \mathrm{~m} \quad$ meter

$54 \mathrm{Mg} \quad$ megagram

$55 \mu \mathrm{g} \quad$ microgram

$56 \mathrm{~mm} \quad$ millimeter

$57 \mathrm{NaOH} \quad$ sodium hydroxide

58 S.e standard error

59 SOC soil organic carbon

60 UC untreated control

61 Key Words

62 Carbon accretion, leaf litter, mineralization, Pinus taeda L., soil size fraction

63

64 


\section{Introduction}

Soil organic carbon (SOC) content is a keystone soil quality parameter and plays a significant role in the global carbon cycle. Yet, the role of root turnover and leaf litter in the maintenance and accretion of SOC across a range of forest/soil types is not well documented. The lower Coastal Plain of the southeastern United States supports 12 million ha of natural and planted loblolly pine (Pinus taeda L.) stands (Baker and Langdon 1990), making it a dominant cover type in in this region. In addition, there are 5.7 million ha of Spodosols (Adegbidi et al. 2002) covering the lower Coastal Plain, which contain some of the largest soil organic carbon stocks in the southeastern United States (Stone et al. 1993). These soils frequently support highly productive pine plantations through intensive silvicultural practices, i.e. genetic selection, fertilization, and understory suppression (Vogel et al. 2011). In contrast, these cover type/soil type systems' potential for increasing belowground $\mathrm{C}$ storage has been described as limited (Shan et al. 2001), due to the excessively sandy, weak-structured soil surface horizons (Richter et al. 1999; Six et al. 2002).

Recent investigations have studied the nature of SOC pools in these forested soils. Sarkhot et al. (2007a, b) revealed the presence of sand-sized aggregates, with increasing degrees of stability and identifiable $\mathrm{C}$ pools of various chemical composition. They reported that only some SOC pools were responsive to management in the short term. Therefore, understanding the development and maintenance of SOC under this cover type/soil type may capitalize not only on the economic worth of pine commercial products, but also include the value of SOC storage. 
The quantitative contributions of $\mathrm{C}$ sources to the formation of SOC pools is being addressed (Rasse et al. 2005) with specific reference to climate change scenarios. Recent advances in the understanding of terrestrial C cycling, particularly below-ground processes, have come from the employment of long-term exclusion studies, the use of stable isotopes, isotopic labeling and molecular-markers (Johnston et al. 2004;

Kuzyakov 2011). The simple approach of using prolonged forest floor removal has been useful in estimating the role leaf litter plays in the formation and maintenance of stable SOC pools. Garten (2009) used prolonged O horizon removal (4.5 years) to show that the aboveground litter of a Tennessee temperate hardwood forest was not a significant source of SOC. Likewise, results from another litter and root manipulation study in place for 5 years in a northeastern hardwood forest, indicated that SOC was not affected by either aboveground litter additions or litter removals (Nadelhoffer et al. 2004).

The potential for aboveground sources of $C$ to contribute to $S O C$ is limited when there is not a mechanism for their biomass to be incorporated into the soil (Quideau et al. 2001). In contrast, large amounts of photosynthetically fixed C are drawn into the soil matrix through root growth and exudations (Farrar et al. 2003, Godbold et al. 2006). A study of intensively managed slash pine (Pinus elliottii var. elliottii Engelm.) plantations showed that $10 \%$ of the total annual primary production was devoted to fine root production, while fine roots only constituted about $2 \%$ of the total tree biomass (Shan et al. 2001), indicating significant turnover rates and inputs of organic carbon to the soil. The microenvironment of fine roots supports large microbial populations and their persistent cell fragment residues (Kindler et al. 2006 and 2009; Simpson et al. 2007; Miltner et al. 2011). Additionally, excretions from root tips and mycorrhizae have 
110 hydrophobic properties that are important for soil aggregate formation and stability

111 (Oades 1978; Czarnes et al. 2000).

112 The overall objective of this study was to explore aspects of the short-term

113 development, maintenance, and fate of SOC in the surface mineral soil of a Spodosol

114 supporting an intensively managed loblolly pine plantation. The soil at the surface

115 provides the best perceived opportunity to observe the most significant impact of the $\mathrm{O}$

116 horizon and fine root turnover in SOC dynamics. The specific objectives of this study

117 were to (1) investigate the short-term whole soil and size fraction changes in SOC

118 naturally occurring to characterize the rate of below-ground accretion in surface soil

119 during the rapid growth phase of juvenile loblolly pine; (2) determine the SOC

120 distribution and inherent mineralization rates of different soil size fractions to determine

121 which size fractions are vulnerable to short-term microbial decomposition; and (3)

122 investigate the short-term cumulative effects of above- and belowground $\mathrm{C}$ inputs on

123 SOC pools via a sequential exclusion experiment.

125 Materials and Methods

126 Experimental Site

127 The study site was nested within a larger field study owned by Rayonier Inc. and 128 designed by the Forest Biology Research Cooperative at the University of Florida. The 129 site was located northwest of Waldo, FL, USA $\left(29.80^{\circ} \mathrm{N}, 82.21^{\circ} \mathrm{W}\right)$. A full description of 130 the study site was provided by Roth et al. (2007). The research was conducted in a 131 densely planted loblolly pine stand. The native ecosystem existing prior to commercial 132 tree production was identified as an upland pine flatwoods ecosystem of the 
133 southeastern U.S. lower Coastal Plain region. It is characterized by flat, wet, low-lying 134 topography with poorly drained, acidic, deep sandy soils. The native ecosystem is 135 maintained by periodic fire events and is described as open, wet pine woodland with a 136 thick understory, and is commonly used for commercial pine plantations. The study site 137 is a typical representation of this specific regional cover/soil type.

The NRCS soil series for the study area was mapped as Pomona fine sand 139 (sandy, siliceous, hyperthermic Ultic Alaquod). In general, the typical soil profile consists 140 of a sandy, A horizon (10YR 3/1) approximately $13 \mathrm{~cm}$ thick extending to a lighter 141 colored, leached E horizon (10 YR 6/1 to 7/1) with an approximate thickness of $47 \mathrm{~cm}$. 142 A well-developed Bh (spodic) horizon occurs from 60 to $90 \mathrm{~cm}$ below the surface and a 143 Bt (argillic) horizon begins at approximately $130 \mathrm{~cm}$. The soil profile is very strongly 144 acidic, $\mathrm{pH}$ ranges from 4.5 to 5.0 . The water table is within 25 to $100 \mathrm{~cm}$ from the surface for 6 months or more during most years (Soil Survey Staff, 2011). During the study period, monthly mean 147 temperatures ranged from an average low of $13^{\circ} \mathrm{C}$ during January and February to an 148 average high of $27^{\circ} \mathrm{C}$ during June, July, and August (NCDC, 2011). At the initiation of 149 the study in May 2007, the region was experiencing extreme drought conditions.

150 Although these conditions improved over the duration of the study, the study period was 151 classified as having abnormally dry conditions (U.S. Drought Monitor website, 2011).

152 Annual mean precipitation documented at the Gainesville Regional Airport, $13 \mathrm{~km}$ from 153 the study site, was $890,1170,1008$, and $1191 \mathrm{~mm}$ for years $2006,2007,2008$ and 1542009 , respectively. The long term annual mean is $1242 \mathrm{~mm}$ for the years $1960-2010$ 155 (NCDC, 2011). 
Following the clear cut harvest of the mature pine plantation, the land was

157 bedded and the current loblolly pine stand was planted in January 2000. Of the original

158 study design described by Roth et al. (2007), only the narrow spacing, high culture

159 treatment in each of the three blocks was used in this study. The three study blocks

were in close proximity to one another, with the greatest separating distance being

approximately $500 \mathrm{~m}$. The planting density was 2,990 stems $^{-1}$, resulting in 128 trees

162

per 0.04 ha treatment plot. The pine stand received understory competition control and

$660 \mathrm{~kg} \mathrm{ha}{ }^{-1}$ of $10-10-10 \mathrm{~N}-\mathrm{P}-\mathrm{K}$ fertilizer plus micronutrients at the time of planting (Roth

et al. 2007). This treatment was managed for optimal growth by using weed control and

an intensive fertilizer regime based on annual foliar analyses. This created and

maintained an open understory throughout the experimental treatment plot described

167 above. At age $10 \mathrm{yrs}$ volume accumulation averaged approximately $258 \mathrm{~m}^{3} \mathrm{ha}^{-1}$

168 (Jokela, unpublished data).

In Situ Field Treatments

The data from this study were based on three in situ field treatments established

172 within the original replicated narrow spacing, high culture treatment described above.

173 Within each original study treatment, the three in situ field treatments were established

174 in the interbed region (the area between bedded planed rows) of the three center rows

175 using a randomized complete block design. Each randomly assigned in situ treatment

176 plot was a permanently marked $0.5 \mathrm{~m}$ by $1 \mathrm{~m}$ area (corners were marked with $1.3 \mathrm{~cm}$

177 diameter PVC pipe). Each of the three interbed regions within a study treatment plot

178 received one randomly placed replication of each of the three in situ treatments. 
Two of the three in situ treatments were designed to prevent $\mathrm{C}$ inputs from

180

181

182

183

184 185

186

187

188

189

190

191

192

193

194

195

196

197

198 entering the soil. The first in situ treatment eliminated the influence of the aboveground sources of $\mathrm{C}$ and is identified as treatment " $\mathrm{L}$ ". This was accomplished by removing the entire $\mathrm{O}$ horizon at the study initiation and keeping the soil bare during the entirety of the study. An additional $0.5 \mathrm{~m}$ of $\mathrm{O}$ horizon was removed from the perimeter of the designated treatment plot area to reduce the $\mathrm{O}$ horizon's influence at the edge, giving a $1.5 \mathrm{~m}$ by $2 \mathrm{~m}$ total area of excluded $\mathrm{O}$ horizon. The entire $1.5 \mathrm{~m}$ by $2 \mathrm{~m}$ bare soil area was covered with shade cloth; aboveground litterfall, plus any sprouting vegetation under the cloth, was removed on a monthly to bimonthly schedule.

The second in situ treatment eliminated all inputs from aboveground litter and root growth (treatment "LR"). In addition to O horizon removal and litterfall exclusion, a lined trench surrounded the treatment plot to prohibit new and existing root growth within the plot. This was accomplished using a $40 \mathrm{~cm}$ deep trench, $0.5 \mathrm{~m}$ from the perimeter of the treatment plot, lining it with aluminum sheet metal, and back filling with soil.

The untreated control (UC) was a marked $0.5 \mathrm{~m}$ by $1 \mathrm{~m}$ area representing the natural soil state of the loblolly pine plantation. Canopy closure in these stands was reached after approximately five years of growth. At study month 0 the trees were in their $7^{\text {th }}$ year of growth and by the end of the study, 31 months later, they were entering their $10^{\text {th }}$ year. 
Soil and Litterfall Sampling

Soil samples were taken from the soil surface to $20 \mathrm{~cm}$ below the surface, a soil depth that included the mixed A horizon and portions of the underlying $E$ horizon. Soil samples were collected at the initiation of the study in May 2007 from the control plots to establish the initial C content. A $1.9 \mathrm{~cm}$ diameter soil push probe was used to collect eight soil samples from 0 to $10 \mathrm{~cm}$ and 10 to $20 \mathrm{~cm}$, and composited for each block to provide a covariate for the initial conditions of the treatment plot. Soil samples were subsequently collected after 31 months of in situ treatment. To maintain the integrity of the in situ plots for future work, three soil subsamples per in situ treatment plot were collected with a $6.5 \mathrm{~cm}$ diameter aluminum cylinder, separated into 0 to $10 \mathrm{~cm}$ and 10 to $20 \mathrm{~cm}$ soil depths, and composited by soil depth.

At the initiation of the study the forest floor was removed from the $L$ and $L R$ plots, oven dried at $70^{\circ} \mathrm{C}$ and weighed. These in situ treatment plots were then covered with shade cloth to prevent litterfall inputs and to buffer any temperature affects due to litter removal. Thermometers placed under the shade cloth and litter layers for the first few months of the study showed no temperature differences by treatment. Litter was

216 collected monthly from the L and LR plots, oven-dried and weighed. An unanticipated commercial pine needle harvest took place in the fall of 2008.

218 The majority of the litter was inadvertently removed from the study areas, including the 219 untreated control plots. However, the commercial process of harvesting pine litter

220 focuses on raking the seasonal needle fall that occurs in the autumn months

221 (September-November) while leaving the more established forest floor intact. In order to 
222 restore the natural condition, newly fallen forest floor material was gathered from a

223 nearby (approximately $300 \mathrm{~m}$ ) undisturbed loblolly stand of the same age and replaced

224 on the control plots. The initial forest floor mass and measured litterfall were used to

225 reestablish the forest floor on the untreated control plots.

226

227 Live Root Observations

228

To ensure that root exclusions successfully eliminated new root growth, the

229 distribution of fine roots was evaluated at the end of the study in all in situ treatment

230 plots. A field method described by Escamilla et al. (1991) based on the relationships

231 among fine root biomass, root length density, and the number of roots crossing a two-

232 dimensional plane was used. A vertical plane of soil was exposed in each treatment plot

233 by trenching. Fine roots protruding from the soil face were counted in a $30 \mathrm{~cm}$ horizontal

234 area at $5 \mathrm{~cm}$ vertical increments to $20 \mathrm{~cm}$.

235

Laboratory Methods

237 Soil fresh mass and moisture content were determined. Bulk density was

238 calculated from the soil volume and mass, and corrected for moisture content. The

239 samples were subsequently air-dried and passed through a $2 \mathrm{~mm}$ mesh sieve. One-

240 hundred $\mathrm{g}$ of the air-dried fine earth fraction soil was then passed through a column of

241 sieves for 5 minutes, using a horizontal shaker and following the method of Sarkhot et

242 al. (2007a). The sieves fractionated the soil into 2000 to $250 \mu \mathrm{m}, 250$ to $150 \mu \mathrm{m}, 150$ to

$24353 \mu \mathrm{m}$ and $<53 \mu \mathrm{m}$ size fractions. Total organic carbon in the coarse size fraction, the

244 fine earth fraction, and the four mineral soil size fractions was measured by loss-on- 
245 ignition (LOI) and then converted to organic $\mathrm{C}$. The $\mathrm{C}$ conversion was based on a 246 pedotransfer function developed from 133 soil samples taken from an adjacent 247 watershed study and described in Azuaje et al. (2012).

$248 \quad$ Mineralization of SOC in each size fraction $\leq 2 \mathrm{~mm}$ was accomplished by using 249 the untreated control soil sampled at 31 months. Twenty grams of air-dried soil from the 250 three larger size fractions and $5 \mathrm{~g}$ of the $<53 \mu \mathrm{m}$ size fraction were moistened to a water 251 holding capacity of $-33 \mathrm{kPa}$, a soil moisture condition relative to field capacity, and 252 placed in a microcosm (container) made of high density polyethylene.

253 The rate of $\mathrm{C}$ mineralization was determined by measuring soil respiration using 254 as alkaline trap method (Anderson, 1982). A liquid based trap of $0.25 \mathrm{M} \mathrm{NaOH}$ was 255 securely placed inside the microcosm of the well-mixed, moist soil samples. The 256 microcosms were then placed in a dark, $30^{\circ} \mathrm{C}$ incubator for a total of $162 \mathrm{~d}$. Moisture 257 content was maintained throughout the study by monitoring the microcosms' weight.

\section{Statistical Methods}

Specific measurements of changes in SOC occurring in the UC treatment were analyzed to evaluate the native condition of SOC. The variables evaluated were bulk 262 density, coarse fraction SOC, fine earth fraction SOC, SOC in individual soil size class 263 fractions, and size fraction $\mathrm{CO}_{2}$ mineralization. The relative percent change over time, 264 defined as the percent change in the variable between the end of the study $\left(T_{2}\right)$ and the 265 beginning of the study $\left(T_{1}\right)$, was used to analyze the effects of the field treatments on 266 bulk density, coarse fraction SOC, fine earth fraction SOC, and SOC in individual soil 267 size class fractions. This approach was required to minimize the uneven variability 
268 determined to be present among treatment plots (Bonate 2000). When necessary the 269 data were log transformed to fit normal distribution patterns prior to statistical analyses. The PROC MIXED model (SAS; Littell et al., 2006) was used to analyze the data,

271 with the inclusion of the fixed factors of soil depth, fraction, time, treatment and

272 interactions of fixed factors. In addition a random effect of plot was included to model

273 the correlation that exists between the observations made at the two soil depths within

274 each treatment plot. Observations were modelled by an autoregressive error structure.

275 Means were considered significantly different at $\alpha \leq 0.1$. This level of significance was

276 chosen based on soil heterogeneity that is particularly inherent in forest soils, making

277 detection of changes in situ SOC more difficult (Haines and Cleveland, 1982; Richter et

278 al. 1999; Conant et al. 2003). Conant et al. (2003) found that resampling micro-plots

279 over short periods of time in forest soil was effective, and that using a lower level of 280 significance was appropriate. When significant main effects and/or interactions were 281 found, multiple mean comparisons and separations were identified using Tukey's HSD 282 test.

\section{Results}

By age $7 \mathrm{yr}$ the forest floor had accumulated a total of $12.7 \mathrm{Mg} \mathrm{ha}^{-1}$ of litterfall.

286 The rate of litterfall statistically increased as the stand aged from 7 to $10 \mathrm{yrs}(p=0.02)$.

287 The total litterfall mass collected during Year 8 was $5.7 \mathrm{Mg} \mathrm{ha}^{-1}$, compared to 9.6 $\mathrm{Mg} \mathrm{ha}^{-}$

$288{ }^{1}$ during Year 10, a 68\% increase in annual litterfall. Total litterfall over the entire 31 289 month study was $22.2 \mathrm{Mg} \mathrm{ha}^{-1}$. 
291 292

293

294

295

296

297

298

299

300

301

302

303

304

305

306

307

308

309

310

311

312 313 total C (30\%). volume basis.

Objective 1. Short-term changes in SOC content under fast growing pine

Soil bulk density (BD) increased with soil depth from $0.93 \mathrm{~g} \mathrm{~cm}^{-3}$ in the $0-10 \mathrm{~cm}$ soil depth to $1.26 \mathrm{~g} \mathrm{~cm}^{-3}$ at $10-20 \mathrm{~cm}$, with no significant change in bulk density over the 31 months of study. Bulk densities were used to calculate SOC expressed on a soil

The coarse fraction (>2 $\mathrm{mm}$ ) SOC had a significant interaction between sampling time and soil depth $(p=0.06)$. Measurements taken at the initiation of the study were significantly different among soil depths, with the $0-10 \mathrm{~cm}$ soil depth containing $2.1 \mathrm{Mg}$ SOC ha- ${ }^{-1}$ and $3.2 \mathrm{Mg} \mathrm{SOC} \mathrm{ha}^{-1}$ in the $10-20 \mathrm{~cm}$ soil depth. At the end of the study period SOC content was 3.1 and $2.3 \mathrm{Mg} \mathrm{SOC} \mathrm{ha}^{-1}$ in the 0 to 10 and 10 to $20 \mathrm{~cm}$ soil depths, respectively (Fig 1).

The SOC $\left(\mathrm{Mg} \mathrm{ha}^{-1}\right)$ in the fine earth fraction $(\leq 2 \mathrm{~mm})$ in the $0-10 \mathrm{~cm}$ soil depth increased by $80 \%$ from 12.2 to $21.9 \mathrm{Mg} \mathrm{SOC} \mathrm{ha}^{-1}$ (s.e. $=2.8$ ), while no significant change in SOC was evident at the $10-20 \mathrm{~cm}$ soil depth $\left(7.5\right.$ to $9.5 \mathrm{Mg} \mathrm{SOC} \mathrm{ha}^{-1}$; time $\mathrm{x}$ sampling depth interaction, $p=0.10$; s.e. $=2.8 ; \mathrm{Fig} 1)$. The $S O C$ in soil size fractions, averaged across both sampling times, exhibited some differences among size fractions and soil depth, $p=0.01$ (Fig 2). SOC was greatest in the $2000-250 \mu \mathrm{m}$ fraction of the 0 $10 \mathrm{~cm}$ layer, while the three smaller size fractions had similar SOC contents. SOC decreased with soil depth for the largest and smallest size fractions. The 2000-250 $\mu \mathrm{m}$ fraction of the $0-10 \mathrm{~cm}$ layer contained $44 \%$ of the total soil $\mathrm{C}$ in that layer. The most striking difference among size fractions in the $10-20 \mathrm{~cm}$ layer was that the $2000-250 \mu \mathrm{m}$ fraction was much lower than its $0-10 \mathrm{~cm}$ counterpart, and also accounted for less of the 
Objective 2. Mineralization potential among soil size fractions

There was an interaction between soil depth and size fraction for specific

317 mineralization rate $\left(\mathrm{mg} \mathrm{C}\right.$ respired $\mathrm{g}^{-1}$ size fraction $\left.C \mathrm{~d}^{-1}\right)(p=<0.01)$. For the $0-10 \mathrm{~cm}$

318 layer, the specific mineralization rate of the $<53 \mu \mathrm{m}$ fraction was statistically lower (over

$31925 \%$ ), with the $150-53 \mu \mathrm{m}$ fraction intermediate in value (Fig 3). In comparison,

320 mineralization rates at the $10-20 \mathrm{~cm}$ layer were similar among all size fractions.

321 Comparing the same size fraction among layers, the significant difference was in the

$322<53 \mu \mathrm{m}$ fraction, where the $10-20 \mathrm{~cm}$ layer was approximately $28 \%$ higher than the $0-10$

$323 \mathrm{~cm}$ layer.

$324 \quad$ Bulk $\mathrm{C}$ mineralization rates were also calculated on a whole soil basis (mg C 325 respired $\mathrm{kg}^{-1}$ fine earth fraction $\mathrm{d}^{-1}$ ) to provide the potential relative contribution by each 326 size fraction and soil depth to whole soil (<2mm fine earth fraction). There was an 327 interaction between soil depth and soil size fraction $(p<0.01)$. The $0-10 \mathrm{~cm}$ soil depth

328 had more mineralizable $C$ than the $10-20 \mathrm{~cm}$ layer, except for the $<53 \mu \mathrm{m}$ fraction, 329 which was not different between soil depths.

Objective 3. Eliminating fresh $C$ inputs and its effect on SOC development and

332 maintenance

The LR in situ treatment significantly reduced the presence of live roots $(p<$ 334 0.01), with a reduction of $75 \%$ and $92 \%$ at the $0-10 \mathrm{~cm}$ and $10-20 \mathrm{~cm}$ soil depths, respectively (Fig 4). While root exclusion was not complete, it greatly reduced the

336 presence and hence influence of root turnover on SOC during the study period. Root 
337 numbers in the $10-20 \mathrm{~cm}$ depth of the UC treatment were 4 times less than the $0-10 \mathrm{~cm}$

338 depth, illustrating the importance of the near surface soil in fine root development and 339 potential turnover.

At the end of the 31 month study period, the LR treatment had a soil bulk density increase $(7 \%)$, while the UC treatment remained unchanged. This resulted in significant

342 differences between these two treatments $(p=0.05)$, with the $L$ treatment being

343 intermediate between UC and LR. These bulk densities were used to calculate SOC on

344 a soil volume basis.

The initial distribution of SOC $\left(\mathrm{Mg} \mathrm{ha}^{-1}\right)$ within the three treatments blocks was skewed with higher levels of SOC in the L and LR treatments versus the UC treatment

347 (Table 1). For this reason, treatment effect was based on the relative change in SOC over the 31 month study period. There was no net increase in SOC of the fine earth

349 fraction $(\leq 2 \mathrm{~mm})$ in the LR treatment of the mean SOC content in the surface $20 \mathrm{~cm}$.

350 The UC treatment had an increase in the surface $20 \mathrm{~cm}$ of approximately $55 \%$ in the 351 mean SOC over the 31 month study period (Table1). Statistical analysis of the 352 treatment effects were evaluated on the relative \% change of SOC content and 353 differences among treatment were significant $(p=0.05)$ and reported a positive $45 \%$ 354 increase in the UC treatment. This change was only evident in the $0-10 \mathrm{~cm}$ layer (Table 355 1). Soil OC in the $L$ treatment was not statistically different than either the UC or LR 356 treatments (Table 1), while the LR treatment demonstrated a reduction in SOC 357 accumulation compared to the UC treatment. In fact, the LR treatment showed no SOC 358 increase over the study period. 
The SOC accumulation in the UC treatment was primarily found in the $0-10 \mathrm{~cm}$

360

361

362

363

364

365

366

367

368

369

370

371

372

373

374

375

376

377

379

380 soil depth, 9.7 Mg ha-1, and secondarily in the $10-20 \mathrm{~cm}$ soil depth, $2.0 \mathrm{Mg} \mathrm{ha}^{-1}$.

Through evaluation of changes in SOC content over time as effected by treatment and soil depth (Table 1), the influence of litter and roots on the change in SOC observed in the UC plots could be estimated. The above ground litter influence in the $0-10 \mathrm{~cm}$ soil depth was estimated from the difference between the change in the UC treatment plots and the $\mathrm{L}$ treatment plots, $\Delta \mathrm{UC}-\Delta \mathrm{L}=3.7 \mathrm{Mg} \mathrm{ha}^{-1}$. This represented $38 \%$ of the total change in SOC in the $0-10 \mathrm{~cm}$ soil depth over the study period. The influence of roots in the $0-10 \mathrm{~cm}$ soil depth was estimated by subtracting change in the $L$ treatment plots from the difference of the $U C$ and $L R$ treatments plots, $(\Delta U C-\Delta L R)-\Delta L=5.9 \mathrm{Mg} \mathrm{kg}$ SOC ha-1 ; a $61 \%$ change of SOC due to the absence of roots.

The effects of exclusion treatments on soil size fractions are shown in Figure 7.

Treatment was a significant main effect in the coarse fraction $(>2 \mathrm{~mm})(p=0.06)$, where $L$ showed a significantly greater \% increase than LR. The LR SOC decreased during the study but no significant change occurred in the UC or L treatments. The SOC from the 2000-250 $\mu \mathrm{m}$ and 250-150 $\mu \mathrm{m}$ size fractions was not significantly affected by treatment. Over $40 \%$ of SOC was lost from the $150-53 \mu \mathrm{m}$ size fraction due to the LR treatment $(p$ $=0.02$ ). There was no treatment effect on SOC in the UC and L plots. The $L$ treatment, due to high variability, did not differ from either the UC or LR treatments.

There was a treatment by soil depth interaction $(p=0.04)$ for the smallest soil size fraction class $(<53 \mu \mathrm{m})$, where the UC treatment more than doubled in SOC content in the 10 to $20 \mathrm{~cm}$ soil layer (Fig 5). Both the L and LR treatments had lower increases in 
381 SOC changes, indicating a possible response to litter removal but not to root removal in 382 this soil fraction. There were no treatment effects at the $0-10 \mathrm{~cm}$ soil depth.

\section{Discussion}

Objective 1. Short-term changes in SOC content under fast growing loblolly pine Intensive management of genetically improved loblolly pines in the US lower Coastal Plain enhances biomass production throughout the rotation (Martin and Jokela, 2004; Vogel et al. 2011). The rate of net primary production typically peaks during the developmental age range observed in this study. In nearby stands of similar genetic quality that received similar management inputs, aboveground net primary production was reported by Martin and Jokela (2004) to be greatest (approximately $22.0 \mathrm{Mg} \mathrm{ha}^{-1} \mathrm{yr}^{-}$ $\left.{ }^{1}\right)$ between ages 8-10 yrs.

Eight to ten years of age is an important phase of stand development for net primary production. The highest rate of increase in annual needlefall occurs during this phase (Gholz et al. 1985; Jokela and Martin 2000) and needlefall rates typically level off at around age 10, when leaf area index culminates. With an assumed correlation between needlefall rate and fine root turnover, one's expectation is that this would also be the phase of greatest SOC accumulation. However, this has never been addressed, particularly in these sandy soils, even though data on relative SOC changes during this phase would be useful to help validate carbon models.

$\mathrm{SOC}$ accretion in the fine earth fraction at the $0-20 \mathrm{~cm}$ soil depth, $4.6 \mathrm{Mg} \mathrm{SOC}$

$402 \mathrm{ha}^{-1}$ soil $\mathrm{yr}^{-1}$, was over $50 \%$ greater than the estimated SOC accretion averaged over 403 the entire rotation of a loblolly pine stand under similar management, soil type, and 
404 genetic quality (3.0 Mg SOC ha ${ }^{-1}$ soil $\mathrm{yr}^{-1}$ in the $0-20 \mathrm{~cm}$ of soil depth; Vogel et al. 2011).

405 Compared to other tree species, these accretion rates appear as high as any and higher

406 than most. Other studies of loblolly pine stands planted following clear cut harvest in

407 the southeastern U.S. lower Coastal Plain region report surface soil C annual accretion

408 rates of $0.5 \mathrm{Mg} \mathrm{ha}^{-1}$ in an $11 \mathrm{yr}$ old well drained, low fertility site (Leggett and Kelting

409 2006) and rates of 6 and $11 \mathrm{Mg} \mathrm{SOC} \mathrm{ha}^{-1} \mathrm{yr}^{-1}$ in the $0-30 \mathrm{~cm}$ soil depth of $5 \mathrm{yr}$ old

410 planted loblolly pine stands, without and with understory suppression, respectively, in

411 poorly drained sites with intensive site preparation (disking, bedding, and fertilization

412 (Laiho et al. 2001). The relative high rates reflect the incorporation of the litter layer

413 during stand establishment and the SOC observations were to the $0-30 \mathrm{~cm}$ soil depth.

414 Soil moisture, site preparation and stand management appear to be an important factor

415 in determining the fate of SOC development and maintenance.

Compared to forests planted in previous land uses other than clear-cut forest the

417 range of SOC accretion rates were not as high. Young post-agricultural forests in New

418 Jersey accrued at annual rates of 0.1 to $0.3 \mathrm{Mg} \mathrm{SOC} \mathrm{ha}^{-1}$ (Lathrop et al. 2011) and 0.07

$419 \mathrm{Mg} \mathrm{SOC} \mathrm{ha}{ }^{-1}$ were reported in $34 \mathrm{yr}$ old post-agricultural loblolly pine in the South

420 Carolina Piedmont region (Richter et al. 1995). In the Pacific Northwest of the USA,

421 soils under Douglas-fir (Pseudotsuga menziesii (Mirb.) Franco) had reported accretion

422 rates ranging from 0.6 to $4.1 \mathrm{Mg} \mathrm{SOC} \mathrm{ha}^{-1}$ (Adams et al. 2005); Scaled estimates of

423 carbon accretion in forest soils of Europe were dependent on how they were modeled

424 but ranged from 0.2 to $0.9 \mathrm{Mg} \mathrm{SOC} \mathrm{ha}^{-1}$ (cited in De Vries et al. 2006); while tree

425 species in India on new mine spoils accrued SOC in the first 4-5 years at rates of 0.1 to

426 1.4 Mg ha-1 $\mathrm{y}^{-1}$ (Singh et al. 2006). A review of long term experiments have shown that 
427 soil carbon can accrete under forests at rates of 0.5 to $2.0 \mathrm{Mg} \mathrm{ha}^{-1} \mathrm{y}^{-1}$ (Dixon et al.

428 1994). Rates measured in this study put this phase of development for this ecosystem

429 in a range of the higher rates for soil carbon accretion in the reviewed literature and may

430 be a result of intensive site preparation, fertilization, understory control and poorly

431 drained soils.

432

Objective 2. Carbon distribution and mineralization potential among soil size fractions

The SOC distribution among fractions within a soil depth was similar to other studies on similar soils, being more concentrated at the soil's surface, and greatest in the 2000-250 $\mu \mathrm{m}$ fraction largely as particulate organic matter (Fig 2; Haile et al. 2007b; Sarkhot et al. 2007b). This exemplifies the small amount of reactive clays and oxides in the soil's mineralogy and a concentration of fine roots and biological activity at the soil's surface in these ecosystems (Van Rees and Comerford 1986; Gholz et al. 1986; Sword 1998; Fierer et al. 2003). This further highlights the need to understand these dynamics 441 in the surface mineral soil.

The specific SOC mineralization of each size fraction was evaluated with the 443 intent to better interpret the SOC changes in objective 3 when the carbon sources for 444 maintenance and accretion of SOC were removed (Fig 3). To the extent that specific 445 mineralization rates measured under controlled conditions reflect SOC quality, the 446 results indicated that SOC mineralization rate, hence quality, showed little differences 447 among size fractions within or between soil depths.

448 The most sizeable differences in quality were in the $2000-250 \mu \mathrm{m}$ fraction of the $449 \quad 0-10 \mathrm{~cm}$ layer and the $<53 \mu \mathrm{m}$ fraction in the $10-20 \mathrm{~cm}$ layer. The explanation for the 450 former difference is that this is the size fraction that receives the greatest amount of 
451 recent SOC from various sources (Sarkhot et al. 2007b) with a high mineralization 452 potential. Yet, this explanation did not hold for the same fraction in the zone just $10 \mathrm{~cm}$ 453 below. This study does not provide the reason for this, but it is consistent with the 454 accretion of SOC in this fraction at 10-20 cm (see untreated control treatment in Fig 5) 455 and the lack of accretion, presumably due to enhanced mineralization, in the $0-10 \mathrm{~cm}$ 456 layer. It also implies that the SOC input to the $2000-250 \mu \mathrm{m}$ fraction at the lower layer is 457 of lower quality; a hypothesis that can be tested in future studies.

The $<53 \mu \mathrm{m}$ fraction has been shown to be comprised of more decomposed and recalcitrant material as well as lesser amounts of freshly added organic matter (Sarkhot et al. 2007b), but that does not explain why the two layers would be significantly 461 different for the same size fraction. These data suggest that a better understanding of 462 SOC cycling within and among size fractions, and how SOC moves between size 463 fractions is warranted.

In general the total soil carbon mineralization from each size fraction was a 465 reflection of the total SOC contained in the fractions and relatively homogeneous 466 mineralization quality of the $\mathrm{C}$ located in the fractions. The sum of the bulk soil 467 mineralization rates for all the fractions in the $0-20 \mathrm{~cm}$ layer, $9.5 \mathrm{mg} \mathrm{kg}^{-1} \mathrm{~d}^{-1}$, was at the 468 upper end of a range (3.4 to $10.6 \mathrm{mg} \mathrm{C} \mathrm{kg}^{-1} \mathrm{~d}^{-1}$ ) reported by Ahn et al. (2009) for SOC 469 located in the top $30 \mathrm{~cm}$ of whole soil in similar Coastal Plain Spodosols in north central

470 Florida. Ahn et al. (2009) utilized similar C mineralization assessment methods as this

471 study by incubating soil samples at $35^{\circ} \mathrm{C}$ at $-33 \mathrm{kPa}$ water holding capacity and

472 measuring $\mathrm{CO}_{2}$ respiration over an $87 \mathrm{~d}$ study period. 
474 Objective 3.Eliminating fresh C inputs and its effect on SOC development and 475 maintenance

Contributions of the total $\mathrm{C}$ input from various sources into the surface soils supporting loblolly pine plantations are influenced by stand conditions (i.e. genetic quality, stand age, planting density, site fertility, and light and water availability; (Albaugh et al. 1998; King et al. 1999; Burkes et al. 2003)). The contributions can be segregated into $\mathrm{C}$ originating from aboveground and belowground sources.

The reported annual litterfall rates for mid-rotation loblolly pine range from 3.0 and 7.0 Mg ha-1, depending on management strategies (Jokela and Martin, 2000). The accumulation of mass in the forest floor is influenced by the long residence time characteristic of pine litter and minimal faunal soil mixing and incorporation of aboveground C residues into the surface mineral soil (Thomas 1968; McBrayer et al. 1977; Piatek and Allen 2001). Most aboveground litter is thought to be utilized by microorganisms that produce enzymes to digest this recalcitrant material (Jorgensen et al. 1980; Berg and McClaugherty 2003; Bardgett et al. 2005). As the forest floor develops with age more advanced stages of decomposition occur and it becomes increasingly populated by fine roots and mycorrhizal fungi (Gholz et al. 1986; Ponge 1991). In the next biotic level observations of meso- and macrofauna in the A horizon of southern U.S. flatwoods pine are primarily mites, ants, and beetle larvae. The frequency of their occurrences has been described as rare when compared to other forests types (Phillips and Fitzpatrick 1999) and characterizes the limited soil mixing events. The primary $\mathrm{C}$ contribution made by the forest floor is presumed to be through $\mathrm{DOC}$ leaching. By mid-rotation, the forest floor begins to develop distinct $\mathrm{Oi}$ and $\mathrm{Oe}$ 
497 horizons. Polglase et al. (1992) reported total labile C concentrations in the Oi and Oe 498 layers as $14 \%$ and $6 \%$ by weight, respectively.

Utilizing available literature and data from this current study, estimations of annual

$500 \mathrm{C}$ inputs and outputs to the surface soil can be made. Forest floor mass at the

501 beginning of this study was $13.0 \mathrm{Mg} \mathrm{ha}^{-1}$. The mean annual aboveground litter additions

502 were $8.6 \mathrm{Mg} \mathrm{ha}^{-1} \mathrm{yr}^{-1}$, which included needles and some coarse woody debris. Loblolly

503 needles have been measured to release approximately $25 \%$ of the $C$ within the first

504 year, followed by a long period of slow release (Jorgensen et al. 1980; Gholz et al.

505 1985). In this study, the maximum annual C release from fresh needlefall would have

506 been approximately $1.1 \mathrm{Mg} \mathrm{C} \mathrm{ha}^{-1}$. This assumes that the entire aboveground litter

507 mass was needles, which likely is an overestimation as a small portion of coarse woody 508 debris was collected with the needlefall.

509 From the available literature of mature loblolly pine stands, the annual contribution 510 of DOC leaching from the bottom of the $\mathrm{O}$ horizon was estimated to add $0.3 \mathrm{Mg} \mathrm{C} \mathrm{ha}^{-1}$

511 of DOC (Richter et al. 1995, 1999; Dosskey and Bertsch 1997); a relatively small

512 amount of the total. By mid-rotation, the forest floor of southern pines is only beginning

513 to develop discrete levels of decomposition. If indeed the source of forest floor DOC is

514 from more decomposed material, this may be an over estimation of $\mathrm{C}$ input.

515 Recent studies have questioned the degree of participation of the $\mathrm{O}$ horizon in

516 mineral SOC formation. A disconnection between the $\mathrm{C}$ of recently added forest litter

517 and the mineral soil has been observed in Tennessee pine-hardwood forests by tracing

518 the decay of $\mathrm{C}-14$ released into the atmosphere from a nearby incinerator (Froberg et

519 al. 2007b). The authors determined that, after four years of various manipulations of C- 
52014 enriched $\mathrm{C}$ additions, only $14 \%$ of the total DOC in the top $15 \mathrm{~cm}$ originated from the

521 C-14 forest floor litter. Similar results were found with C-13 isotope labeling to trace

522 DOC from fresh C into the soil (Hagedorn et al. 2004). Hagedorn et al. (2004) found that

$5235-10 \%$ of the labeled DOC at the $5-10 \mathrm{~cm}$ soil depth had originated from fresh litter and

524 recent rhizodeposition. The authors also determined that recently deposited DOC was

525 preferentially mineralized in a soil incubation study. The majority of DOC that reached

526 the mineral soil surface was thought to originate from the more decomposed Oe

527 horizon, while more recently released DOC was mineralized in the forest floor (Froberg

528 et al. 2007a).

529 It is possible, to some degree, that nutrient cycling in the forest floor is discoupled

530 from the mineral soil in southern pine ecosystems. By mid-rotation, the forest floor in

531 loblolly pine has been reported to immobilize nitrogen and phosphorus (Piatek and Allen

532 2000). This may be an indication of microbial populations in the forest floor utilizing the

533 labile $\mathrm{C}$ released from the fresh litter inputs. Results of these findings correspond with

534 radiocarbon data that identified the age of DOC in forested surface soils around 20-30

535 yrs and its presence in the soil related to microbial processes (Trumbore et al. 1992;

536 Guggenberger et al. 1994; Tegen \& Dörr 1996).

537 When the forest floor was excluded from adding $\mathrm{C}$ to the soil in this study, the

538 SOC was suppressed but not significantly different than the untreated control plots. This

539 suppressed effect may be an indication the ecosystem's high precipitation rate and

540 poorly drained soil is elevating the microbial activity in the O horizon (Hass et al. 2010).

541 In more poorly drained landscapes, where the forest floor litter is more consistently

542 moist and under more persistent decomposition, loblolly pine litter may have a greater 
543 opportunity as a C source to SOC development. Although data were not presented by

544 block in this study, it was noted the study's most poorly drained block showed the

545 largest negative affect on SOC development in the aboveground exclusion treatment

546 plots.

However, the absence of a significant difference between the litter exclusion plots and the untreated control plots supports the perception the $\mathrm{O}$ horizon plays a limited

549 role in SOC development at the near surface mineral soil layers. Corresponding forest

550 soil studies that used prolonged $\mathrm{O}$ horizon removal in several temperate deciduous

551 forest ecosystems found minimal or absent effects on the surface mineral SOC

552 (Nadelhoffer et al. 2004; Garten 2009; Kramer et al. 2010). In addition, southern pine

553 litter raking studies report surface SOC to be unaffected after five to seven years of

554 consecutive litter removal (Ross et al. 1994; Blazier et al. 2008).

In contrast the success of the soil trenching method in inhibiting new fine root

556 growth prevented the SOC accretion that was experienced in the untreated control

557 plots, indicating a primary dependence on subsurface processes. The trenching method

558 may have temporarily elevated the SOC accretion as the existing roots decompose,

559 creating an underestimation of the dependence on subsurface sources of C. Short-term

560 effects of eliminating the above- and belowground inputs of $\mathrm{C}$ resulted in higher soil bulk

561 density and a loss of SOC in the coarse $(>2 \mathrm{~mm}$ ) and 150-53 $\mu \mathrm{m}$ fraction (Table 2, Fig $5625)$.

563 This study measured a $55 \%$ increase in SOC in the fine earth fraction, primarily at 564 the $0-10 \mathrm{~cm}$ soil depth. The measured annual net change of SOC in the $0-20 \mathrm{~cm}$ soil 565 depth of 4.6 $\mathrm{Mg} \mathrm{C} \mathrm{ha}^{-1}$ was more than 3 times higher than the estimated $\mathrm{C}$ addition from 
566 fine root turnover $\left(1.4 \mathrm{Mg} \mathrm{C} \mathrm{ha}^{-1}\right)$. If this net SOC accretion is as dependent on

567 belowground sources of $\mathrm{C}$, it may suggest fine root production is higher in this

568 ecosystem than other estimates.

569 The increases of SOC among the $2000-250 \mu \mathrm{m}$ and $250-150 \mu \mathrm{m}$ sand size

570 fractions were expected in the control and aboveground litter exclusion plots. These

571 fractions have been characterized as containing large amounts of recently added

572 organic material, significant amounts of particulate matter, and aggregates combined

573 with fine roots and fungal hyphae (Oades 1978; King et al. 2002; Sarkhot et al. 2007a,

574 b). For example, the diameter of loblolly pine ephemeral fine roots range from 2000-

$575400 \mu \mathrm{m}$, with turnover rate estimated at 166-300 days depending on root diameter (King

576 et al. 2002). Mycorrhizal associated fine roots also fall within this range, $600-200 \mu \mathrm{m}$,

577 but observed turnover rates have been reported to be much slower at 507 days (King et 578 al 2002).

Eliminating new sources of $\mathrm{C}$ for an extended period of time revealed a SOC dependence of root inputs to the $>2 \mathrm{~mm}$ and $150-53 \mu \mathrm{m}$ fractions. Lateral coarse roots

581 and associated root branches are the primary constituent of the $>2 \mathrm{~mm}$ size class in 582 these sandy soils. Roots are also suspected as the principle source of $C$ in the $150-53$ $583 \mu \mathrm{m}$ fraction. It is the very fine root class $(<1 \mathrm{~mm})$ that are identified as ephemeral and 584 dependent on continual regeneration. The very fine roots are dynamic but not uniform in 585 function and morphology (King et al. 2002); it is the first order roots, the smallest fine 586 roots, that experience the highest rate of turnover (Pregitzer et al. 2002b). First order 587 root activity appeared to be significant in maintaining SOC in the $150-53 \mu \mathrm{m}$ fraction, 588 possibly as these small roots turnover. 
590

591

592

593

594

595

596

597

598

599

600

601

602

603

604

605

606

607

608

609

610

\section{Conclusion}

Carbon storage in the sandy soils of the lower Coastal Plain region is particularly sensitive to disturbances and land management. Through a more complete understanding of SOC cycling in managed lower Coastal Plain pine stands, additional strategies can be developed to manage and forecast SOC accumulation and storage through the life of a stand's rotation (18-25 yrs) and through successive rotation plantings. As a dominant ecosystem across the Southeast US, highly productive pine plantations offer opportunities to capitalize on their ability to build SOC in the surface soil despite relatively high $\mathrm{C}$ mineralization rates. This research suggests that the juvenile fast-growth stage of tree development is a crucial phase in SOC accretion under intensively managed loblolly pine growing on Spodosols of the lower Coastal Plain. Soil OC accretion during the rapid growth phase represents some of the highest SOC accretion figures found in the literature for forest stands. Root turnover was found to be the most significant source of SOC for maintenance/accretion during this stage, with root turnover representing approximately $60 \%$ of the SOC change.

Although forest soil studies are prone to high spatial variability and changes in SOC can be difficult to measure, this study's sampling approach successfully captured changes over time. Future studies will require a focus on minimizing variability to expose more subtle responses and to include further evaluation of above-ground litter's role in SOC development. One approach would be to identify a relevant elementary soil volume for sampling to reduce sampling and maximize information. While this was a 
611 single location study, its favorable comparison to literature and to other carbon studies

612 in similar soil/climatic conditions as cited above speaks to its wider applicability.

613

614 Acknowledgements

615 We would like to thank the University of Florida's Forest Biology Research Cooperative 616 and Rayonier, Inc. for the opportunity to utilize the research site for this study. We also 617 acknowledge and thank Dr. Salvador Gezan for assistance provided with the statistical 618 analysis.

619

620

621

622 
Literature Cited

625

626

627

628

629

630

631

632

633

634

635

636

637

638

639

640

641

642

643

644

645

646

647

648

649

650

651

652

653

654

655

656

657

658

659

660

661

662

Abbott, I., 1989. The influence of fauna on soil structure. P. 39-50 in Animals in Primary Succession: The Role of Fauna in Reclaimed Lands, Majer, J.D. (ed). Cambridge University Press, Cambrige.

Adams, A.B., R.B. Harrison, R.S. Sletten, B.D. Strahm, E.C. Turnblom, and C.M. Jensen. 2005. Nitrogen-fertilization impacts on carbon sequestration and flux in managed coastal Douglas-fir stands of the Pacific Northwest. For. Ecol. and Manag. 220: 313-325.

Adegbidi, H.G., E.J. Jokela, N.B. Comerford, and N.F. Barros. 2002. Biomass development of intensively managed loblolly pine plantations growing on Spodosols in the southeastern USA. For. Ecol. and Manag. 167: 91-102.

Ahn, M.Y., A.R. Zimmerman, N.B Comerford., J.O. Sickman, and S. Grunwald. 2009. Carbon mineralization and labile organic carbon pools in the sandy soils of a north Florida watershed. Ecosystems. 12:672-685.

Anderson J. 1982. Soil respiration. P. 842-845 in Methods of soil analysis. Part 2. 2nd Ed., Page A.L., R.H. Miller, and D.R. Keeney (eds.). Am. Soc. of Ag., Inc., Madison.

Azuaje, E.I., N.B. Comerford, W.G. Harris, J.B. Reeves III, and S. Grunwald. 2012. Loblolly and slash pine control organic carbon in soil aggregates and carbon mineralization. Forest Ecol. Manag. 263:1-8.

Baddeley, J .A. and C.A. Watson. 2005. Influences of root diameter, tree age, soil depth and season of fine root survivorship in Prunus avium. Plant Soil. 276:15-22.

Baker, J.B. and O.G. Langdon, 1990. Pinus taeda L., Loblolly Pine, pp. 497-512. In R.M. Burns and B.H. Honkala (eds.), Silvics of North America, Vol. 1, Conifers, U.S.D.A. For. Serv. Agric. Handbk. 654, Washington, D.C.

Bardgett, R.D., Bowman, W.D., Kaufmann, R. \& Schmidt, S.K. 2005. A temporal approach to linking aboveground and belowground ecology. Trends Ecol. Evol. 20: 634-641.

Berg, B. and C. McClaugherty. 2003. Plant Litter: Decomposition, Humus Formation, Carbon Sequestration, 1st edn. Springer, Berlin. 
663 Blazier M.A., W. B. Patterson, S.L. Hotard. 2008. Straw harvesting, fertilization, and 664 fertilizer type alter soil microbiological and physical properties in a loblolly pine 665 plantation in the mid-south USA. Biol. Fert. Soils. 45:145-153.

666

Bonate, P.L. 2000. Analysis of Pretest-Posttest Designs. Boca Raton: Chapman \& 668 Hall/CRC. p. 75-89

669

670

Burkes, E.C., R.E. Will, G.A. Barron-Gafford, R.O. Teskey, B. Shiver. 2003. Biomass

671 partitioning and growth efficiency of intensively managed Pinus taeda and Pinus elliottii

672 stands of different planting densities. Forest Sci. 49:224-234.

673

Conant, R.T., G.R. Smith, K. Paustain. 2003. Spatial variability of soil carbon in forested and cultivated sites: implications for change detection. J. Environ. Qual. 32:278-286. deposition on carbon sequestration in European forests and forest soils. Global Change Biol 12: 1151-1173.

Dixon, R., J. Winjum, K. Andrasko, J. Lee, and P. Schroeder, 1994: Integrated systems: assessment of promising agroforest and alternative land-use practices to enhance carbon conservation and sequestration. Climatic Change, 30, 1-23.

Dosskey, M.G. and P.M. Bertsch. 1997. Transport of dissolved organic matter through a 690 sand forest soil. Soil Sci. Soc. Am. J. 61:920-927.

Eissenstat, D.M., C.E. Wells, R.D. Yanai, J.L. Whitbeck. 2000. Building roots in a changing environment: implications for root longevity. New Phytol. 147: 33-42. estimate pine root distribution. Soil Sci. Soc. Am. J. 55: 1722-1726. 
Fröberg, M. D. Berggren Kleja, F. Hagedorn. 2007a. The contribution of fresh litter to dissolved organic carbon leached from a coniferous forest floor. Eur. J. Soil Sci. 58:108114. 136

Fröberg, M., P.M. Jardine, P.J. Hanson, D.E. Todd, J.R. Tarver. 2007b. Low dissolved organic carbon input from fresh litter to deep mineral soils. Soil Sci. Soc. Am. J. 71:347354

Garten, C.T. 2009. A disconnect between O horizon and mineral soil carbon:

Implications for soil C sequestration. Oecologica. 35:218-226.

Gaudinski, J.B., S.E. Trumbore, E.A. Davidson, A.C. Cook, D. Markewitz, D.D. Richter. 2001. The age of fine-root carbon in the three forests of the eastern United States measured by radiocarbon. Oecologia. 129:420-429.

Gholz, H. L.; C.S. Perry, W.P. Cropper, L.C. Hendry. 1985. Litterfall, decomposition, and nitrogen and phosphorus dynamics in a chronosequence of slash pine (Pinus elliottii) plantations. Forest Sci. 31:463-478.

Gholz, H.L., L.C. Hendry, and W.P. Cropper Jr. 1986. Organic matter dynamics of fine roots in plantations of slash pine (Pinus elliottii) in north Florida. Can. J. For. Res. 16:529-538.

Godbold, D.L., M.R. Hoosbeek, M. Lukac, M. F. Cotrufo, I.A. Janssens, R. Ceulemans, A.Polle, E.J. Velthorst, G. Scarascia-Mugnozza, P. De Angelis, F. Miglietta, and A. Peressotti. 2006. Mycorrhizal hyphal turnover as a dominant process for carbon input into soil organic matter. Plant Soil. 281:15-24.

Guggenberger, G., W. Zech, H.R. Schulten. 1994. Formation and mobilization pathways of dissolved organic matter: evidence from chemical structural studies of organic matter fractions in acid forest floor solutions. Org. Geochem. 21:51-66.

Hagedorn, F., M. Saurer, P. Blaser. 2004. A 13C tracer study to identify the origin of dissolved organic carbon in forested mineral soils. Eur. J. Soil Sci. 55:91-100.

Haines, S.G. and G. Cleveland. 1982. Seasonal variation in properties of five forest soils in southwest Georgia. Soil Sci. Soc. Am. J. 45:139-143.

Haile, S.G, P.K.R. Nair, and V.D Nair. 2007. Carbon storage of different soil-size fractions in Florida silvopastoral systems. J. Environ. Qual. 37:1789-1797. 
743 Hass, A., M.G. Messina, T.D. Rogers. 2010. Soil carbon after midrotation phosphorus

744

745

746

747

748

749

750

751

752

753

754

755

756

757

758

759

760

761

762

763

764

765

766

767

768

769

770

771

772

773

774

775

776

777

778

779

780

781

782 fertilization of loblolly pine (Pinus taeda L.) stands in east Texas. Soil Sci. 175:382-389.

Jokela, E.J. and T.A. Martin. 2000. Effects of ontogeny and soil nutrient supply on production, allocation, and leaf area efficiency in loblolly and slash pine stands. Can. J. For. Res. 30:1511-1524.

Johnston, C.A., P. Groffman, D. D. Breshears, Z. G. Cardon, W. Currie, W. Emanuel, J. Gaudinski, R. B. Jackson, K. Lajtha, K. Nadelhoffer, D. Nelson Jr, W. M. Post, G. Retallack, and L. Wielopski. 2004. Carbon cycling in soil. Front. Ecol. Environ. 2:522528.

Jorgensen, J.R., C.G. Wells, L.J. Metz. 1980. Nutrient changes in decomposing loblolly pine forest floor. Soil Sci. Soc. Am. J. 44: 1307-1314.

Kindler R, A. Miltner, H.H. Richnow, and M. Kastner. 2006. Fate of gram-negative bacterial biomass in soil-mineralization and contribution to SOM. Soil Biol. Biochem. 38:2860-2870.

Kindler R, A. M. Miltner, H. H. Thullner, M. Richnow, and M Kastner. 2009. Fate of bacterial biomass-derived fatty acids in soil and their contribution to soil organic matter. Org. Geochem. 40:29-37.

King, J.S., T.J. Albaugh, H.L. Allen, L.W. Kress. 1999. Stand-level allometry in Pinus taeda as affected by irrigation and fertilization. Tree Physiol. 19: 769-778.

King, J.S., T.J. Albaugh, H.L. Allen, M. Buford, B.R. Strain, P. Dougherty. 2002. BelowGround Carbon Input to Soil Is Controlled by Nutrient Availability and Fine Root Dynamics in Loblolly Pine. New Phyto. 154:389-398.

Knoepp, J.D., D.C. Coleman, D.A. Crossley Jr., J.S. Clark. 2000. Biological indices of soil quality: an ecosystem case study of their use. For. Ecol. and Manag.138:357-368.

Kramer, C., S. Trumbore, M. Fröberg, L.M.C. Dozal, D. Zhang, X. Xu, G.M. Santos, P.J. Hanson. 2010. Recent (<4 year-old) leaf litter is not a major source of microbial carbon in a temperate forest mineral soil. Soil Biol. Biochem. 42:1028-1037.

Kuzyakov, Y. 2011. How to link soil C pools with CO2 fluxes? Biogeosciences. 8:15231537. 
Laiho, R., F. Sanchez, A. Tiarks, P. M. Dougherty, C. C. Trettin. 2001. Impacts of intensive forestry on early rotation trends in site carbon pools in the southeastern US. For. Ecol. and Manag.174:177-189.

Lathrop, R.G., B Clough, A Cottrell, J Ehrenfeld, F Felder, E.J. Green, D. Specca, C. Vail, M. Vodak, M. Xu, and Y. Zhang. 2011. Assessing the potential for New Jersey forests to sequester carbon and contribute to greenhouse gas emissions avoidance. New Jersey Dept. Environ. Protect, Div. Parks and For., State Forestry Serv. http://crssa.rutgers.edu/projects/carbon/RU Forest Carbon final.pdf

Leggett, Z.H., D.L. Kelting. 2006. Fertilization effects on carbon pools in loblolly pine plantations on two upland sites. Soil Science Society of America 70: 279-286.

Littell, R.C., G.A. Milliken, W.W. Stroup, R.D. Wolfinger, and O. Schabenberger. 2006. SAS for mixed models. 2nd ed. SAS Institute Inc., Cary, N.C

Lussenhop, J., 1992. Mechanisms of microarthropod-microbial interactions in soil. Adv. Ecol. Res. 23:1-33.

Matamala, R., M.A. Gonzales-Meler, J.D. Jastrow, R.J. Norby, W.H. schesinger. 2003. Impacts of fine root turnover on forest NPP and soil $C$ sequestration potential. Science. 302:1385-1387.

Martin, T.A. and E.J. Jokela. 2004. Developmental patterns and nutritional impact radiation use efficiency component in southern pine stands. Ecol. App. 41:1839-1854.

McBrayer, J.F., J.M. Ferris, L.J. Metz, C.S. Gist, B.W. Cornaby, Y. Kitazawa, T. Kitazawa, J.G. Wernz, G.W. Krantz, H. Jensen. 1977. Decomposer invertebrate populations in the U.S. forest biomes. Pedobiologia. 17:89-96.

Miltner, A., P. Bombach, B. Schmidt-Brücken, and M. Kästner. 2011. SOM genesis: microbial biomass as a significant source. Biogeochemistry. Online only. http://dx.doi.org/10.1007/s10533-011-9658-z. Accessed 04/04/2012

Nadelhoffer, K. J., R. D. Boone, R. D. Bowden, J. D. Canary, J. Kaye, P. Micks, A. Ricca, J. A. Aitkenhead, K. Lajtha, and W. H. McDowell. 2004. The DIRT experiment: litter and root influences on forest soil organic matter stocks and function. P. 300-315 in Forests in Time: The Environmental Consequences of 1000 Years of Change in New England, D. Foster and J. Aber (eds). Synthesis Volume of the Harvard Forest LTER Program. Oxford University Press. 
823

824

825

826

827

828

829

830

831

832

833

834

835

836

837

838

839

840

841

842

843

844

845

846

847

848

849

850

851

852

853

854

855

856

857

858

859

860

861

862

863
NCDC, National Climate Data Center [Internet]. Monthly surface data, Gainesville Regional Airport, Gainesville, FL 2007-2009. Available from: http://cdo.ncdc.noaa.gov, accessed October 14, 2011.

Oades, J.M. 1978. Mucilages at the root surface. J. Soil Sci. 29:1-16.

Okada, K., T. Satomura, A. Kinoshita, T. Horikoshi, K. Yasue, M. Fukuda, A. Yamada. 2011. Difference of pine ectomycorrhizal biomass in relation to forest conditions. Mycoscience. 52:59-64.

Quideau, S.A., O.A. Chadwick, S.E. Trumbore, J.L. Johnson-Maynard, R.C. Graham, M.A. Anderson. 2001. Vegetation control on soil organic matter dynamics. Organic Geochemistry. 32:247-252.

Phillips, D.H. and E.A. Fitzpatrick. 1999. Biological influences on the morphology and micromorphology of selected Podzols (Spodosols) and Cambisols (Inceptisols) from the eastern United States and north-east Scotland. Geoderma. 90:327-364.

Piatek, K. B. and H.L. Allen. 2000. Are forest floors in mid-rotation stands of loblolly pine (Pinus taeda) a sink for nitrogen and phosphorus? Can. J. For. Res. 31:1164-1174.

Polglase, P.J., Jokela, E.J., and Comerford, N.B. 1992. Nitrogen and phosphorus release from decomposing needles of southern pine plantations. Soil Sci. Soc. Am. J. 56: 914-920.

Ponge, J.F. 1991. Succession of fungi and fauna during decomposition of needles in a small area of Scots pine litter. Plant Soil. 138: 99-113.

Ponge, J.F., P. Arpin, G. Vannier. 1993. Collembolan response to experimental perturbations of litter supply in a temperate forest ecosystem. Eur. J. Soil Biol. 29:141153.

Pregitzer, K.S. 2002. Fine roots of trees: a new perspective. New Phytol. 154:267-273.

Rasse, D.P., C. Rumpel, and M.F. Dignac. 2005. Is soil carbon mostly root carbon? Mechanisms for a specific stabilization. Plant Soil. 269:341-356.

Richter, D.D., D. Markewitz, J.K. Dunsomb, P.R. Heine, C.G. Wells, A. Stuanes, H.L. Allen, B. Urrego, K. Harrison, G. Bonani, and W.W McFee. 1995. Carbon cycling in a loblolly pine forest: implications for the missing carbon sink and for the concept of soil. 
P233-251 in Carbon Forms and Functions in Forest Soils, Kelly, J.M. (ed.), Soil Sci. Soc. Am., Madison, WI.

Richter, D.D., D. Markewitz, S.E. Trumbore, and C.G. Wells. 1999. Rapid accumulation and turnover of soil carbon in a re-establishing forest. Nature. 400:56-58.

Ross, S., W.H. McKee, M. Mims. 1994. Loblolly and longleaf pine responses to litter raking, prescribe burning and nitrogen fertilization. P. 220-224 in The Eighth Biennial Southern Silvicultural Research Conference, M. B. Edwards (ed.), USDA Forest Service, Asheville.

Roth, B.E., E.J. Jokela, T.A. Martin, D.A. Huber, and T.L. White. 2007. Family $x$ environment interactions for selected loblolly and slash pine plantations in the southeastern United-States. For. Ecol. and Manag. 238:175-188.

Sarkhot, D.V., N.B. Comerford, E.J. Jokela, J.B. Reeves III, and W.G. Harris. 2007a. Aggregation and aggregate carbon in a forested southeastern coastal plain spodosol. Soil Sci. Soc. Am. J. 71: 1779 - 1787.

Sarkhot, D.V., N.B. Comerford, E.J. Jokela, and J.B. Reeves III. 2007b. Effects of forest management intensity on carbon and nitrogen content in different soil size fractions of a north Florida spodosol. Plant Soil 24:291-303.

Sayer E.J, J.S. Powers, E.V.J. Tanner. 2007. Increased Litterfall in Tropical Forests Boosts the Transfer of Soil CO2 to the Atmosphere. PLoS ONE 2:e1299.

Shan J., L.A. Morris, and R.L. Hendrick. 2001. The effects of management on soil and plant carbon sequestration in slash pine plantations. J. App. Ecol. 38:932-941.

Simpson, A.J., M.J. Simpson, E. Smith, and B.P. Kelleher. 2007. Microbially derived inputs to soil organic matter: are current estimates too low? Environ. Sci. Technol. 41:8070-8076.

Singh, A. N., Zeng, D. H. and Chen, F. S. 2006. Effect of young woody plantations on carbon and nutrient accretion rates in a redeveloping soil on coalmine spoil in a dry tropical environment, India. Land Degrad. Dev., 17: 13-21.

Six, J., R.T. Conant, E.A. Paul, and K. Paustian. 2002. Stabilization mechanisms of soil organic matter: Implications for C-saturation of soils. Plant Soil. 241:155-176. 
904 Soil Survey Staff, Natural Resources Conservation Service, United States Department 905 of Agriculture. Web Soil Survey. Available online at http://websoilsurvey.nrcs.usda.gov/. 906 Accessed 10/01/2011.

914 Tegen, I. and H. Dörr. 1996. 14C measurements of soil organic matter, soil CO2 and 915 dissolved organic carbon (1987-1992). Radiocarbon. 38:247-251.

Thomas, W.A. 1968. Decomposition of loblolly pine needles with and without addition of dogwood leaves. Ecology. 49:568-571.

\section{Stone, E.L., W.G. Harris, R.B. Brown and R.J. Kuehl. 1993. Carbon Storage in Florida} Spodosols. Soil Sci. Soc. Am. J. 57:179-182.

Sword, M.A., 1998. Seasonal development of loblolly pine lateral roots in response to stand density and fertilization. Plant Soil. 200:21-25.

Trumbore, S.E., S.L.Schiff, R. Aravena, R. Elgood. 1992. Sources and transformation of dissolved organic carbon in the Harp Lake forested catchment: the role of soils.

Radiocarbon. 34:626-635.

U.S. Drought Monitor. National Drought Mitigation Center (NDMC), Center at the University of Nebraska-Lincoln, contact Brian Fushs. U.S. summary maps animation 2006-2009. Available online: http://drought.unl.edu/dm. Accessed 12/6/11.

Van Rees, K.C.J., and N.B. Comerford. 1986. Vertical root distribution and strontium uptake of a slash pine stand on a Florida Spodosol. Soil Sci. Soc. Am. J. 50:1042-1046. 


\section{List of Tables}

Table 1. Means of soil organic carbon (SOC) $\mathrm{kg} \mathrm{ha}^{-1}$ measured in the fine earth fraction ( $\leq 2 \mathrm{~mm})$ effected by in situ field treatment and soil depth $(0-10 \mathrm{~cm}$ and $10-20$ $\mathrm{cm}$ ) at the study's initiation $\left(T_{1}\right)$ and after 31 months $\left(T_{2}\right)$. Right column shows significant differences in the statistical analysis of the relative $\%$ change of soil organic carbon (SOC) at the $0-20 \mathrm{~cm}$ soil depth in the fine earth fraction $(\leq 2 \mathrm{~mm}$ ) after 31 months of exclusion treatment (Trt. main effect, $p=0.05$ ) Values are LS means of relative \% change with standard error bars. Different letters signify mean separations with $\alpha \leq 0.10$.

Table 2. Effects of in situ exclusion treatments and soil depth $(0-10 \mathrm{~cm}$ and $10-20 \mathrm{~cm})$ on soil organic carbon (SOC) $\mathrm{kg} \mathrm{ha}^{-1}$ at the study's initiation $\left(\mathrm{T}_{1}\right)$ and after 31 months $\left(\mathrm{T}_{2}\right)$ for each size fractions and the relative \% change of SOC of the five physical size soil fractions are compared. Statistical evaluations of each fraction were preformed individually, LS means with standard error bars and probability values are reported in the table. A treatment by soil depth interaction was only found in the $<53 \mu \mathrm{m}$ fraction was significant and the $0-10$ $\mathrm{cm}$ and $10-20 \mathrm{~cm}$ soil depths. Different letters signify mean separations with $\alpha$ $\leq 0.10$ 


\section{List of Figures}

Figure 1. Two separate statistical evaluations of soil organic carbon (SOC) content in the untreated control coarse soil fraction $(>2 \mathrm{~mm})$ and fine earth fraction $(\leq 2$ $\mathrm{mm}$ ) in the $0-10 \mathrm{~cm}$ and $10-20 \mathrm{~cm}$ soil depths measured at the study's initiation $\left(T_{1}\right)$ and after 31 months $\left(T_{2}\right)$; months by soil depth interaction $>2$ $\mathrm{mm} p=0.06, \leq 2 \mathrm{~mm} p=0.10$. Values reported are LS means with standard error bars and the treatment by soil depth interaction probability values. Different letters signify mean separations with $\alpha \leq 0.10$

Figure 2. Distribution of soil organic carbon (SOC kg ha-1) among soil size fractions averaged across time for two soil depths in an Ultic Alaquod supporting an intensively managed loblolly pine stand in north central Florida. Soil C values reported are LS means with standard error bars, $p=0.01$. Different letters signify mean separations with $\alpha \leq 0.1$

Figure 3. Specific soil C mineralization $\left(\mathrm{mg} \mathrm{g}^{-1}\right.$ size fraction $\left.\mathrm{C} \mathrm{d}^{-1}\right)$ of soil size fractions at two depths after $162 \mathrm{~d}$ laboratory incubation at $30^{\circ} \mathrm{C}$ were effected by soil depth and size fraction $(p<0.01)$. Soil C respiration values reported are LS means and standard error bars. Different letters signify mean separations with $\alpha \leq 0.1$

Figure 4. . At the end of the study, a vertical profile inside each of the treatment plots was exposed and live roots counted in area increments of $30 \mathrm{~cm}$ across $\times 10$ $\mathrm{cm}$ depth. Effects of in situ exclusion treatments significantly reduced the 
presence of live roots $(p<0.01)$ on the presence of live roots in the aboveplus belowground (LR) exclusions. The root counts are reported as LS means with standard error bars. Different letters signify mean separations with $\alpha \leq$ 0.10

Figure 5 . The relative $\%$ change of SOC among five physical size soil fractions after 31 months of exclusion treatment are compared. Statistical evaluations of each fraction were preformed individually. Exclusion treatment main effects at the 0-20 $\mathrm{cm}$ soil depth are shown for all size fractions except the $>53 \mu \mathrm{m}$ fraction were a treatment by soil depth interaction was found $(p=0.04)$. LS means with standard error bars are reported refer to Table 2 for probability values of treatment main effects. Different letters signify mean separations with $\alpha \leq$ 0.10 


\begin{tabular}{|c|c|c|c|c|c|}
\hline \multicolumn{6}{|c|}{ Effects of Exclusion Treatment on Fine Earth Fraction $(\leq 2 \mathrm{~mm})$} \\
\hline Treatment & $\begin{array}{c}\text { Soil } \\
\text { Depth }\end{array}$ & $\begin{array}{c}\mathrm{T}_{1} \\
\text { Mean SOC } \\
\mathrm{Mg} \mathrm{ha}^{-1}\end{array}$ & $\begin{array}{c}\mathrm{T}_{2} \\
\text { Mean SOC } \\
\text { Mg ha }^{-1}\end{array}$ & $\begin{array}{c}\mathrm{T}_{2}-\mathrm{T}_{1} \\
\text { Mean SOC } \\
\text { Mg ha }^{-1}\end{array}$ & $\begin{array}{c}\text { Relative \% } \\
\text { Change SOC } \\
0-20 \mathrm{~cm} \\
\text { Trt } p=0.05\end{array}$ \\
\hline \multirow{2}{*}{ UC } & $0-10 \mathrm{~cm}$ & 12.2 & 21.9 & 9.7 & \multirow{2}{*}{$46 \%{ }^{a}$} \\
\hline & $10-20 \mathrm{~cm}$ & 7.5 & 9.5 & 2.0 & \\
\hline \multirow{2}{*}{ L } & $0-10 \mathrm{~cm}$ & 19.5 & 25.5 & 6.0 & \multirow{2}{*}{$14 \%$ ab } \\
\hline & $10-20 \mathrm{~cm}$ & 15.3 & 12.3 & -3.0 & \\
\hline \multirow{2}{*}{ LR } & $0-10 \mathrm{~cm}$ & 19.5 & 19.6 & 0.1 & \multirow{2}{*}{$-3 \% b$} \\
\hline & $10-20 \mathrm{~cm}$ & 11.9 & 9.5 & -2.4 & \\
\hline
\end{tabular}

Table 1. Means of soil organic carbon (SOC) $\mathrm{kg} \mathrm{ha}^{-1}$ measured in the fine earth fraction $(\leq 2 \mathrm{~mm})$ effected by in situ field treatment and soil depth $(0-10 \mathrm{~cm}$ and $10-20$ $\mathrm{cm}$ ) at the study's initiation $\left(T_{1}\right)$ and after 31 months $\left(T_{2}\right)$. Right column shows significant differences in the statistical analysis of the relative $\%$ change of soil organic carbon (SOC) at the $0-20 \mathrm{~cm}$ soil depth in the fine earth fraction ( $\leq 2 \mathrm{~mm}$ ) after 31 months of exclusion treatment (Trt. main effect, $p=0.05$ ) Values are LS means of relative \% change with standard error bars. Different letters signify mean separations with $\alpha \leq 0.10$. 


\section{Effects of Exclusion Treatment on Five Size Fractions}

\begin{tabular}{|c|c|c|c|c|c|}
\hline Size Fraction & Effect & $\begin{array}{l}\text { Soil } \\
\text { Depth }\end{array}$ & Treatment & $\begin{array}{c}\mathrm{T}_{2}-\mathrm{T}_{1} \\
\mathrm{Mg} \mathrm{ha}^{-1}\end{array}$ & $\begin{array}{c}\text { \%Change } \\
\text { SOC }\end{array}$ \\
\hline \multirow{3}{*}{$>2 \mathrm{~mm}$} & \multirow{3}{*}{ Trt $p=0.06$} & \multirow{3}{*}{$0-20 \mathrm{~cm}$} & UC & -1.5 & $-5 \%$ ab \\
\hline & & & $\mathrm{L}$ & 1.9 & $16 \%^{a}$ \\
\hline & & & LR & -2.7 & $-31 \%^{b}$ \\
\hline \multirow{3}{*}{$2000-250 \mu \mathrm{m}$} & \multirow{3}{*}{$\operatorname{Trt} p=0.30$} & \multirow{3}{*}{$0-20 \mathrm{~cm}$} & $\overline{U C}$ & 5.9 & $46 \%$ \\
\hline & & & $\mathrm{L}$ & 3.7 & $9 \%$ \\
\hline & & & LR & 3.4 & $16 \%$ \\
\hline \multirow{3}{*}{$250-150 \mu \mathrm{m}$} & \multirow{3}{*}{$\operatorname{Trt} p=0.78$} & \multirow{3}{*}{$0-20 \mathrm{~cm}$} & $\overline{U C}$ & 0.4 & $22 \%$ \\
\hline & & & $\mathrm{L}$ & 1.6 & $30 \%$ \\
\hline & & & LR & 1.3 & $21 \%$ \\
\hline \multirow{3}{*}{$150-53 \mu \mathrm{m}$} & \multirow{3}{*}{ Trt $p=<0.02$} & \multirow{3}{*}{$0-20 \mathrm{~cm}$} & $\mathrm{UC}$ & 2.4 & $38 \%^{a}$ \\
\hline & & & $\mathrm{L}$ & -0.2 & $-5 \%$ ab \\
\hline & & & LR & -0.6 & $-46 \%{ }^{b}$ \\
\hline \multirow{6}{*}{$>53 \mu \mathrm{m}$} & \multirow{6}{*}{$\begin{array}{c}\text { Soil Depth } \\
\times \text { Trt } \\
p=0.04\end{array}$} & $0-10 \mathrm{~cm}$ & \multirow{2}{*}{ UC } & -0.1 & $4 \%^{b}$ \\
\hline & & $10-20 \mathrm{~cm}$ & & 2.5 & $110 \%^{a}$ \\
\hline & & $0-10 \mathrm{~cm}$ & \multirow[t]{2}{*}{ L } & 1.8 & $29 \%^{b}$ \\
\hline & & $10-20 \mathrm{~cm}$ & & 1.1 & $34 \%^{\mathrm{b}}$ \\
\hline & & $0-10 \mathrm{~cm}$ & \multirow{2}{*}{ LR } & 0.5 & $12 \%^{b}$ \\
\hline & & $10-20 \mathrm{~cm}$ & & 1.0 & $44 \%^{b}$ \\
\hline
\end{tabular}

Table 2. Effects of in situ exclusion treatments and soil depth $(0-10 \mathrm{~cm}$ and $10-20 \mathrm{~cm})$ on soil organic carbon (SOC) $\mathrm{kg} \mathrm{ha}^{-1}$ at the study's initiation $\left(\mathrm{T}_{1}\right)$ and after 31 months $\left(T_{2}\right)$ for each size fractions and the relative $\%$ change of SOC of the five physical size soil fractions are compared. Statistical evaluations of each fraction were preformed individually, LS means with standard error bars and probability values are reported in the table. A treatment by soil depth interaction was only found in the $<53 \mu \mathrm{m}$ fraction was significant and the $0-10$ $\mathrm{cm}$ and $10-20 \mathrm{~cm}$ soil depths. Different letters signify mean separations with $\alpha$ $\leq 0.10$ 


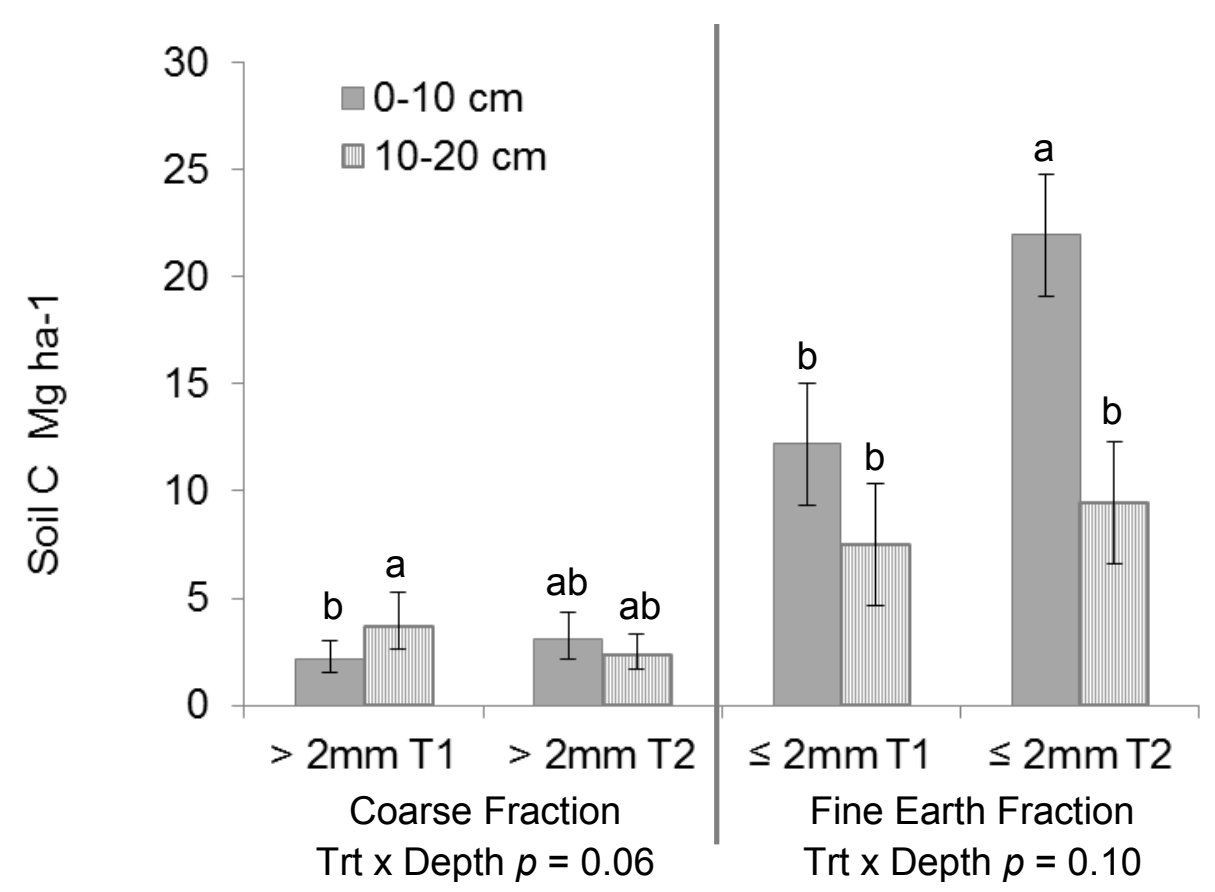

Figure 1. Two separate statistical evaluations of soil organic carbon (SOC) content in the untreated control coarse soil fraction $(>2 \mathrm{~mm})$ and fine earth fraction $(\leq 2$ $\mathrm{mm}$ ) in the $0-10 \mathrm{~cm}$ and $10-20 \mathrm{~cm}$ soil depths measured at the study's initiation $\left(T_{1}\right)$ and after 31 months $\left(T_{2}\right)$; months by soil depth interaction $>2$ $\mathrm{mm} p=0.06, \leq 2 \mathrm{~mm} p=0.10$. Values reported are LS means with standard error bars and the treatment by soil depth interaction probability values. Different letters signify mean separations with $\alpha \leq 0.10$ 


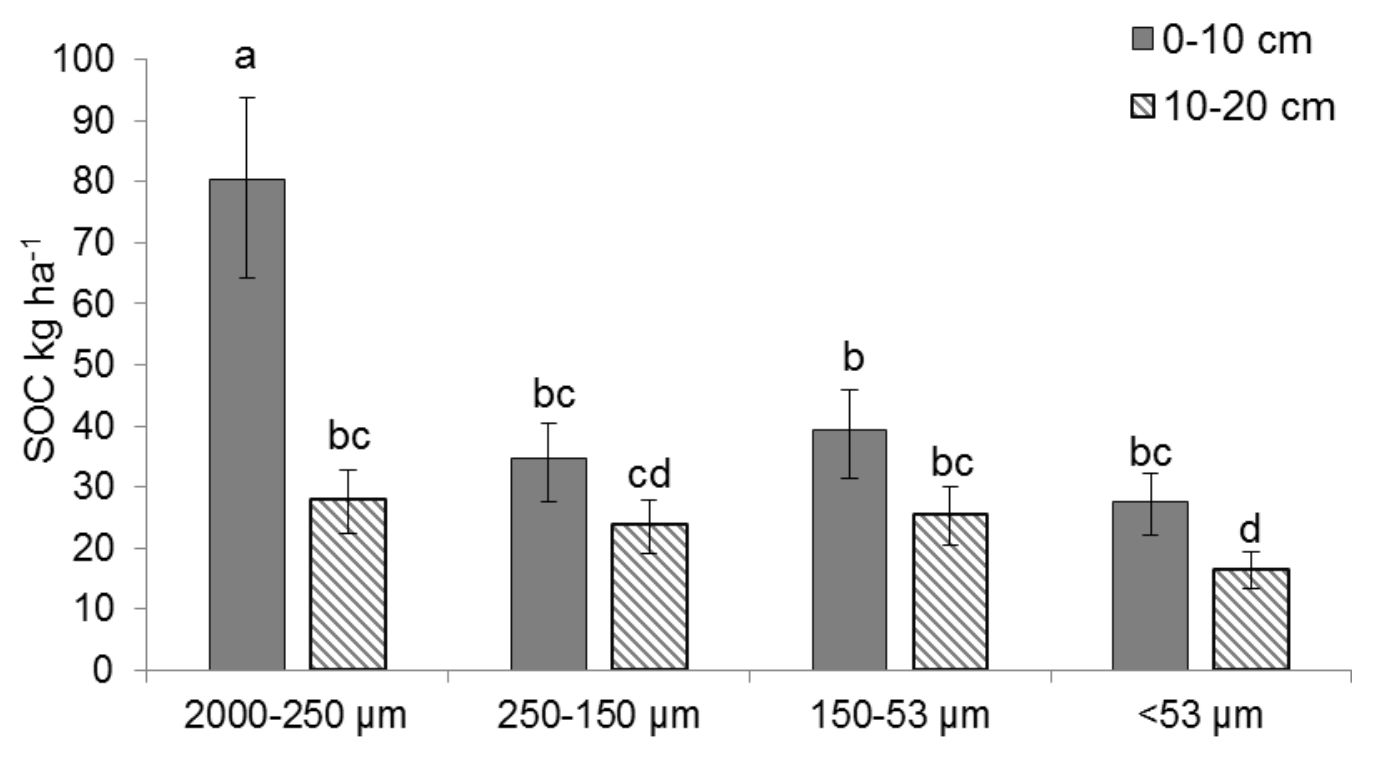

Figure 2. Distribution of soil organic carbon ( $\mathrm{SOC} \mathrm{kg} \mathrm{ha-1)} \mathrm{among} \mathrm{soil} \mathrm{size} \mathrm{fractions}$ averaged across time for two soil depths in an Ultic Alaquod supporting an intensively managed loblolly pine stand in north central Florida. Soil C values reported are LS means with standard error bars, $p=0.01$ Different letters signify mean separations with $\alpha \leq 0.1$ 


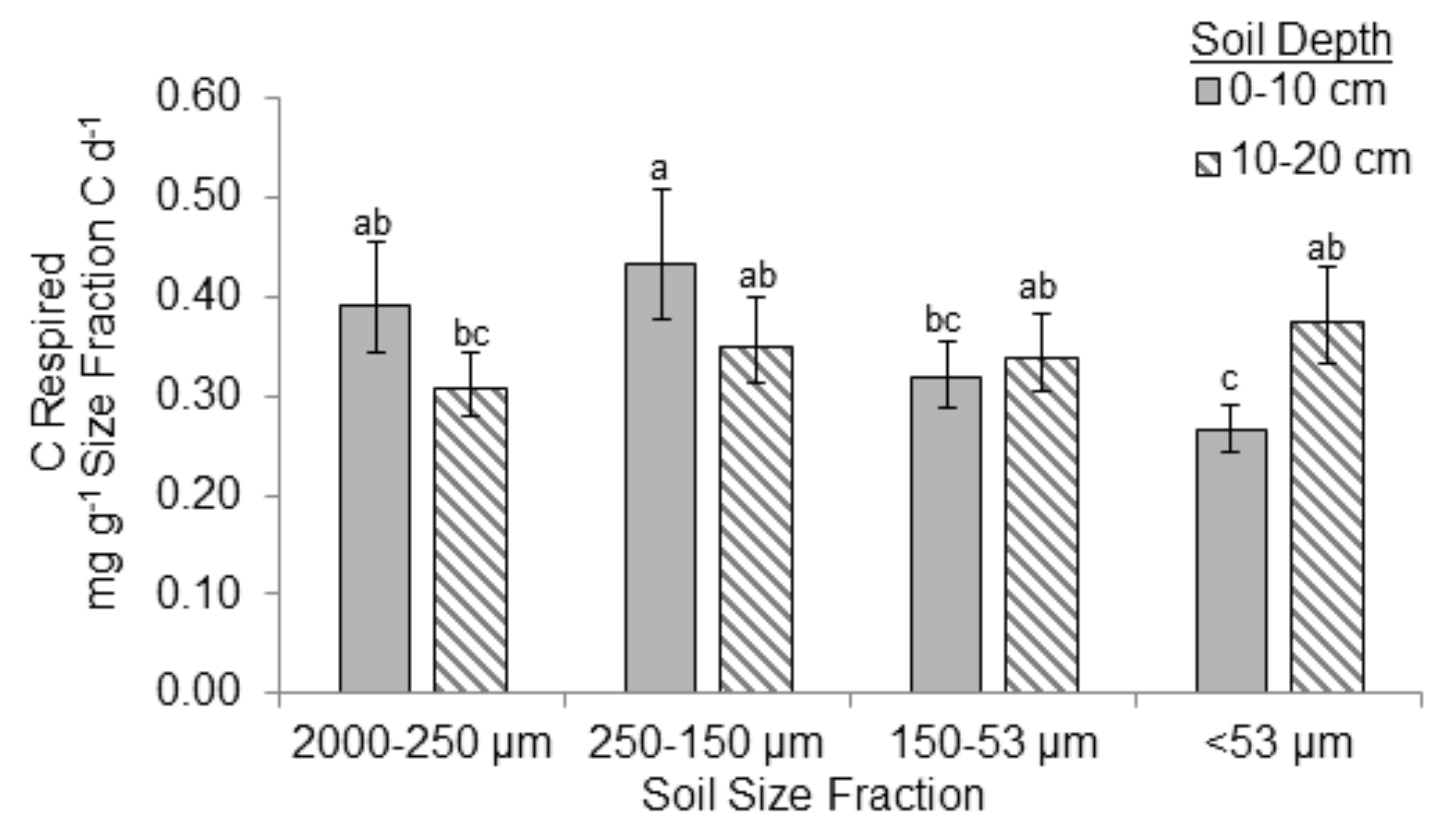

Figure 3. Specific soil C mineralization $\left(\mathrm{mg} \mathrm{g}^{-1}\right.$ size fraction $\left.\mathrm{C} \mathrm{d}^{-1}\right)$ of soil size fractions at two depths after $162 \mathrm{~d}$ laboratory incubation at $30^{\circ} \mathrm{C}$ were effected by soil depth and size fraction $(p<0.01)$. Soil C respiration values reported are LS means and standard error bars. Different letters signify mean separations with $\alpha \leq 0.1$ 


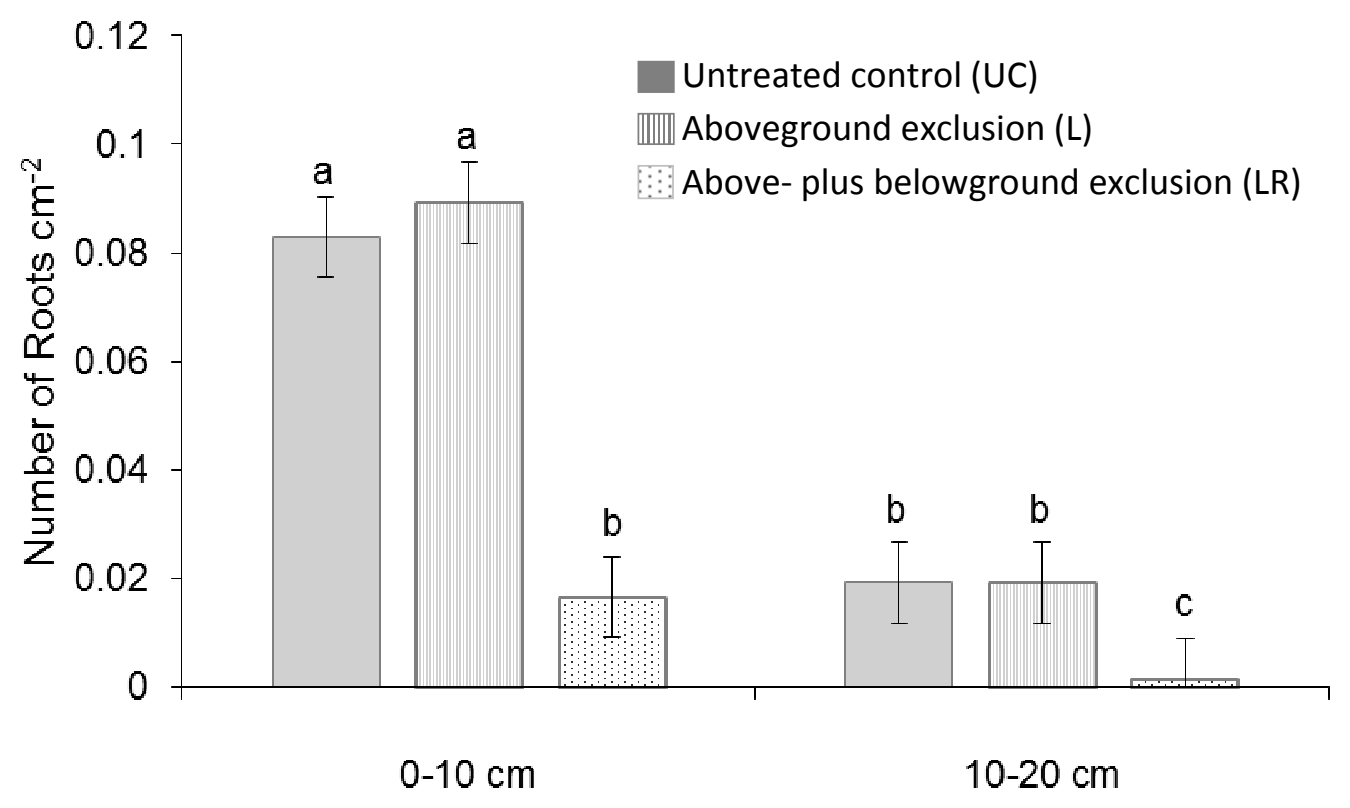

Figure 4. . At the end of the study, a vertical profile inside each of the treatment plots was exposed and live roots counted in area increments of $30 \mathrm{~cm}$ across $\times 10$ $\mathrm{cm}$ depth. Effects of in situ exclusion treatments significantly reduced the presence of live roots $(p<0.01)$ on the presence of live roots in the aboveplus belowground (LR) exclusions. The root counts are reported as LS means with standard error bars. Different letters signify mean separations with $\alpha \leq$ 0.10 


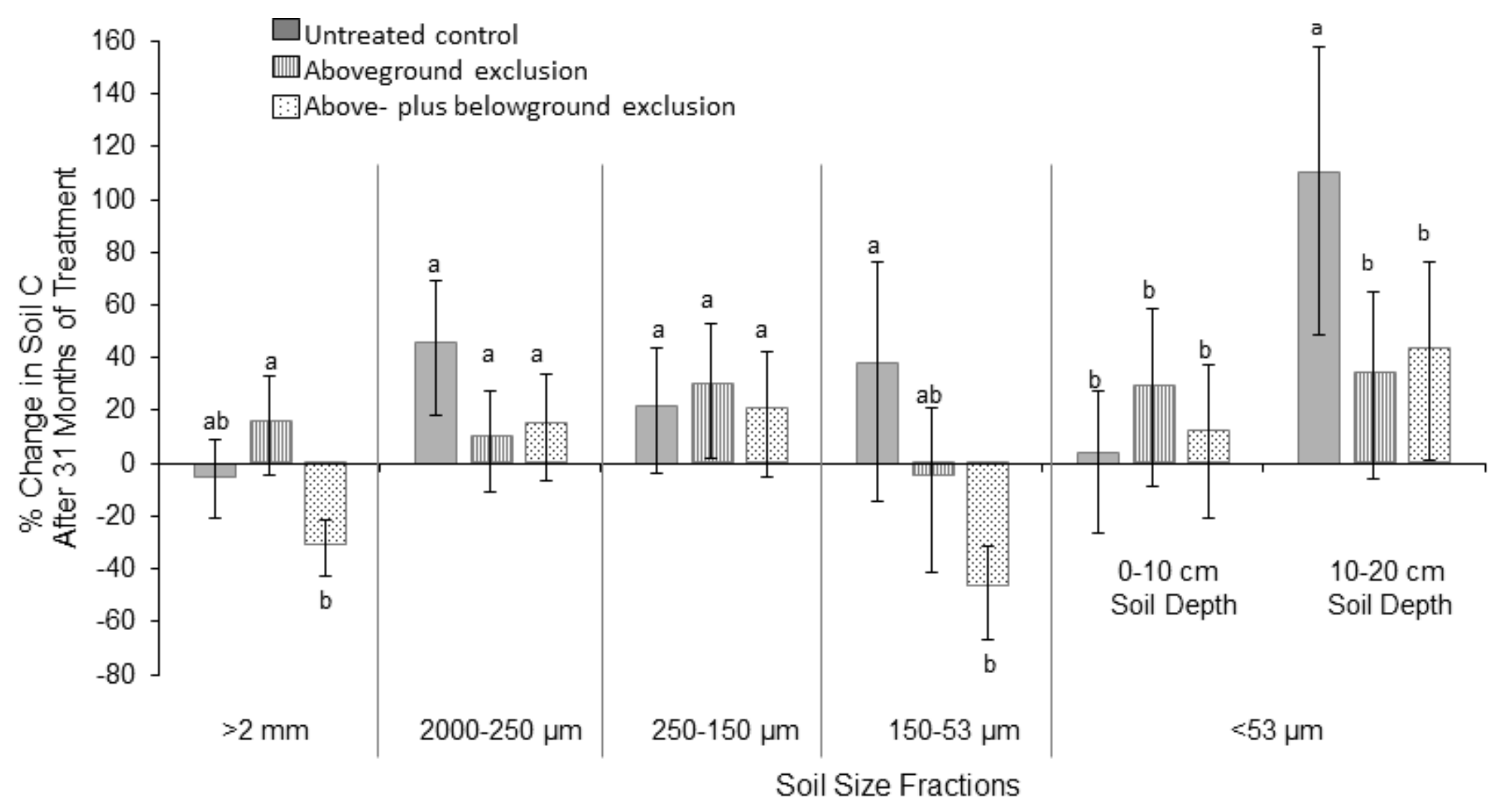

Figure 5. The relative $\%$ change of SOC among five physical size soil fractions after 31 months of exclusion treatment are compared. Statistical evaluations of each fraction were preformed individually. Exclusion treatment main effects at the $0-20 \mathrm{~cm}$ soil depth are shown for all size fractions except the $>53 \mu \mathrm{m}$ fraction were a treatment by soil 
depth interaction was found $(p=0.04)$. LS means with standard error bars are reported refer to Table 2 for probability values of treatment main effects. Different letters signify mean separations with $\alpha \leq 0.10$ 